\title{
HUBUNGAN KURIKULUM 2013 DENGAN MOTIVASI BELAJAR PESERTA DIDIK DI SMK PELITA CIAMPEA
}

\section{RELATIONSHIP OF 2013 CURRICULUM WITH MOTIVATION LEARNING STUDENTS IN PELITA CIAMPEA VOCATIONAL SCHOOL}

\author{
Wahyu Bagja Sulfemi, ${ }^{1}$ Abdul Qodir ${ }^{2}$ \\ STKIP Muhammadiyah Bogor \\ surel:wahyubagja@gmail.com
}

\begin{abstract}
The purpose of this study was to find out the perceptions of students about the 2013 curriculum, to find out the motivation of students in learning, to determine the relationship between learners' perceptions of the 2013 curriculum and learning motivation of Pelita Ciampea Vocational School students, and research lecturers at STKIP Muhammadiyah Bogor. From the results of the study with a total sample of 57 people obtained results (1) Perception of students about the 2013 curriculum at Pelita Ciampea Vocational School has a positive phenomenon, as evidenced by the maximum value that can be obtained by students is 185, the highest score is 175, the lowest 111, the average average 147.74. (2) The learning motivation of students at Ciampea Vocational School has a positive phenomenon, as evidenced by the results of the questionnaire with the maximum value that can be obtained at 135, the highest score of 126, the lowest 90, while the average is 105.72. (3) From the results of the moment product correlation test the relationship between learners 'perceptions of the 2013 curriculum and students' learning motivation has a value of 0.969 while the r-table value is 0.266 , and $0.969>0.266$ or $r$-count $>r$-table. Thus it can be concluded that $\mathrm{HO}$ is rejected and $\mathrm{HI}$ is accepted or in other words there is a positive relationship between variables $X$ (students' perceptions of the 2013 curriculum) with variable $Y$ (student motivation). The level of relationship between variable $X$ and variable $Y$ lies in the interval 0.80-1.00 which means that the relationship between the two is very strong.
\end{abstract}

Keywords: 2013 curriculum, learning motivation, SMK students

\begin{abstract}
ABSTRAK
Tujuan penelitian ini untuk mengetahui persepsi peserta didik tentang kurikulum 2013, Untuk mengatahui motivasi peserta didik dalam pembelajaran, untuk mengetahui hubungan antara persepsi peserta didik tentang kurikulum 2013 dengan motivasi belajar peserta didik SMK Pelita Ciampea, dan penelitain dosen di STKIP Muhammadiyah Bogor. Dari hasil penelitian dengan jumlah sampel sebanyak 57 orang didapat hasil Persepsi peserta didik tetang kurikulum 2013 di SMK Pelita Ciampea memiliki fenomena yang positif, terbukti dari nilai maksimal yang dapat diperoleh peserta didik yaitu 185, nilai tertinggi 175, terendah 111, rata-rata 147,74. (2) Motivasi belajar peserta didik di SMK Ciampea memiliki fenomena yang positif, terbukti dari hasil angket dengan nilai maksimal yang dapat diperoleh sebesar 135, nilai tertinggi 126, terendah 90, sedangkan rata-ratanya 105,72. (3) Dari hasil uji korelasi produk momen hubungan antara persepsi peserta didik tentang kurikulum 2013 dengan motivasi belajar peserta didik memiliki nilai sebesar 0,969 sedangkan nilai r-tabel 0,266, dan 0,969>0,266 atau r-hitung $>$ r-tabel. Dengan demikian dapat disimpulkan bahwa H0 ditolak dan H1 diterima atau dengan kata lain terdapat hubungan yang positif antara variabel X (persepsi peserta didik tentang kurikulum 2013) dengan variabel Y (motivasi belajar peserta didik). Adapun tingkat hubungan antara variabel X dan variabel Y terletak pada interval 0,80-1,00 yang berarti tingat hubungan keduanya sangat kuat.
\end{abstract}

Kata Kunci : kurikulum 2013, motivasi belajar, peserta didik SMK 


\section{PENDAHULUAN}

SMK merupakan salah satu lembaga pendidikan yang bertanggungjawab untuk menciptakan sumber daya manusia yang memiliki kemampuan, keterampilan dan keahlian, sehingga lulusannya dapat mengembangkan kinerja apabila terjun dalam dunia kerja. Pendidikan SMK bertujuan untuk meningkatkan kemampuan peserta didik agar dapat mengembangkan diri sejalan dengan perkembangan ilmu pengetahuan, teknologi dan kesenian, serta menyiapkan peserta didik untuk memasuki lapangan kerja dan mengembangkan sikap profesional.

Dalam Kamus Besar Bahasa Indonesia kata motivasi yang berarti "dorongan yang timbul pada diri seseorang secara sadar untuk melakukan suatu tindakan dengan tujuan tertentu. Atau usaha yang dapat menyebabkan seseorang atau kelompok orang tertentu bergerak melakukan sesuatu karena ingin mencapai tujuan yang dikehendakinya atau mendapat kepuasan dengan perbuatannya". (Kamus Besar Bahasa Indonesia, $2012: 765)$.

Menurut Mc. Donald, dalam Sardiman, A.M. motivasi adalah perubahan energi dalam diri seseorang yang ditandai dengan munculnya "feeling" dan didahului dengan tanggapan terhadap adanya tujuan. Dari pengertian yang dikemukakan Mc. Donald ini mengandung tiga elemen penting. (Sardiman, A.M. 2011 : 73).

Sedemikian banyaknya pembahasan tentang motivasi dalam pembelajaran itu telah menghasilkan definisi motivasi yang banyak pula. Namun demikian, pada intinya motivasi dapat diartikan sebagai: “(1) Dorongan yang timbul pada diri seseorang, secara disadari atau tidak disadari, untuk melakukan tindakan dengan tujuan tertentu; (2) Usaha-usaha yang dapat menyebabkan seseorang atau kelompok orang tertentu tergerak melakukan sesuatu karena ingin mencapai tujuan yang di inginkan.”

Dari dua definisi motivasi di atas, menjadi jelas bahwa motivasi dapat dibagi menjadi dua jenis yaitu: Motivasi yang berasal dari dalam diri seseorang dan Motivasi dari diluar yang berupa usaha pembentukan dari orang lain. (Mohammad Asrori, 2009 :183). Motivasi dapat juga dikatakan serangkaian usaha untuk menyediakan kondisi-kondisi tertentu, sehingga seseorang mau dan ingin melakukan sesuatu, dan bila ia tidak suka, maka akan berusaha untuk meniadakan atau mengelakkan perasaan tidak suka itu. Jadi motivasi itu dapat dirangsang oleh faktor luar tetapi motivasi itu tumbuh didalam diri seseorang. Peserta didik belajar didorong oleh kekuatan mentalnya. Kekuatan mental itu 
berupa keinginan, perhatian, kemauan atau cita-cita. Kekuatan tersebut dapat tergolong rendah atau tinggi. Motivasi dipandang sebagai dorongan mental yang menggerakan dan mengarahkan prilaku manusia termasuk prilaku belajar. Dalam motivasi terkadang adanya keinginan yang mengaktifkan, menggerakan, penyaluran, dan mengarahkan sikap dan prilaku individu belajar. ( Dimyanti dan Mujiono, 2010: 80). Dalam kegiatan belajar, motivasi dapat dikatakan sebagai "keseluruhan daya penggerak di dalam diri peserta didik yang menimbulkan kegiatan belajar, yang menjamin kelangsungan dari kegiatan belajar dan yang memberikan arah pada kegiatan belajar, sehingga tujuan yang dikehendaki oleh subjek belajar itu dapat tercapai”. (Sardiman, A.M. 2011 :75) Seseorang dikatakan telah belajar kalau sudah terdapat perubahan tingkah laku dalam dirinya. Perubahan tersebut terjadi sebagai akibat dari interaksi dengan lingkungannya, tidak karena pertumbuhan fisik atau kedewasaan, tidak karena kelelahan, penyakit atau terpengaruh obat-obatan. Kecuali itu, perubahan tersebut harus bersifat relatif permanen, tahan lama dan mantap, tidak berlangsung sesaat saja.

Belajar adalah sebuah proses yang kompleks yang didalamnya terkandung beberapa aspek bertambahnya jumlah pengetahuan dan danya kemampuan mengingat dan memproduksi dengan penerapan pengetahuan, menyimpulkan makna, menafsirkan dan mengaitkannya dengan realitas, dan danya perubahan sebagai pribadi.

Kurikulum merupakan seperangkat rencana dan program pendidikan yang digunakan sebagai acuan oleh lembaga penyelenggara pendidikan yang disesuaikan dengan jenjang dan kebutuhan peserta didik serta dengan memperhatikan budaya lokal.

Kurikulum 2013 adalah kurikulum yang dikembangkan dengan berbasis pada pencapaian kompetensi sangat diperlukan sebagai instrumen untuk mengarahkan peserta didik menjadi: 1) Manusia berkualitas yang mampu dan proaktif menjawab tantangan zaman yang selalu berubah, 2) Manusia terdidik yang beriman dan betakwa kepada tuhan yang maha esa, berakhlak mulia, sehat, berilmu, cakap, kreatif, dan mandiri. 3) Warga negara yang demokratis dan bertanggung jawab. ( Republik Indonesia, Undangundang no. 20 th. 2003)

Pada kurikulum 2013 kompetensi lulusan yang diharapkan memiliki perimbangan antara aspek kognitif, psikomotorik, dan afektif. Sehingga harapannya generasi Indonesia kedepannya memiliki akhlak yang mulia ditunjang oleh pengetahuan dan kerampilan sebagai modal hidup mandiri di masyarakat.

Ketiga aspek ini saling melengkapi satu sama lain, seandainya satu aspek saja 
yang dihilangkan misalkan aspek afektif, maka kita akan menemukan orang-orang yang pandai, terampil tapi tidak bermoral atau menghalalkan segala cara untuk memperoleh tujuannya.

Baik guru ataupun pihak sekolah memiliki pertimbangan khusus untuk menentukan model pembelajaran yang akan digunakan pada setiap materi dan kompetensi yang diharapkan. Beberepa model pembelajaran yang digunakan dalam kurikulum 2013 sama saja dengan model yang biasa digunaka.

Berikut ini beberapa model pembelajaran dalam kurikulum 2013 : (1) Model PAKEM (Pertisipatif, Aktif, Kreatif, Efektif, dan Menyenangkan). Pembelajaran partisipatif adalah proses pembelajaran yang melibatkan peserta didik secara optimal. Pembelajaran aktif adalah pembelajaran yang melibatkan aktifitas peserta didik (self discovery), pembelajaran kreatif adalah pembelajaran yang bertujuan untuk memunculkan memotivasi dan kreatifitas peserta didik, pembelajaran menyenangkan adalah pembelajaran yang menjadikan peserta didik belajar tanpa ada tekanan atau rasa takut (joyfull learning). (2) Model ASSURE. Model ASSURE (Analyze Learners,States Objectives,Select Methodes, Media, and Material, Utilize Media and Materials,Utilize Media and Materials, Requere Learner Participation, Evaluated and Revise) yang biasa disebut dengan model berorientasi kelas . (3) Model Berorientasi Produk. Model ini merupakan model desain pembelajaran untuk menghasilkan sebuah produk, biasanya media pembelajaran yang digunakan, misalnya vidio pembelajaran, multimedia pembelajaran, atau modul. (4) Model Bella H. Bannaty. Model pembelajaran ini merupakan model yang berorientasi pada tujuan pembelajaran. Sehingga, penyusunan instrumen tes yang akan dipakai pun dilakukan pada tahapan awal desain sistem penbelajaran. Berikut langkah-langkah yang diterapkan pada model pembelajaran Bella H. Bannaty: (5) Model Gagne dan Briggs. Model pembelajaran ini pada prinsipnya merupakan model pembelajaran yang bersandarkan pada prinsip antara tujuan yang hendak dicapai, strategi yang dipakai untuk mencapai tujuan tersebut, dan evaluasi keberhasilannya. Model pebelajaran ini juga berorientasi pada rancangan sistem dengan sasaran guru yang bekerja sebagai perancang maupun tim pengembang intruksional yang beranggotakan guru, administrator, ahli bidang studi, ahli evaluasi, ahli media, dan perancang intruksional. (6) Model ADDIE. Model ADDIE (Analysis-DesginDevelopment-Implementation-Evaluation). (6) Model Desain Sistem Intruksional atau 
Pembelajaran Berorientasi Pencapaian Kompetensi (DSI-PK). Model pembelajaran yang dipakai pada kurikulum 2013 sebenarnya memiliki kemiripan dengan Kurikulum Berbasis Kompetensi (KBK) ataupun Kurikulum Tingkat Satuan Pendidikan (KTSP) yakni dengan model Cara Belajar Peserta didik Aktif (CBSA). Namun, penekanan pembelajaran pada kirikulum baru ini lebih kepada ketercapaian kompetensi atau lebih dikenal dengan model Desain Sistem Intruksional atau Pembelajaran Berorientasi Pencapaian Kompetensi (DSI-PK). (Riskha pratama, dkk, 2010 :7)

Demikian juga metode pembelajaran Kurikulum 2013 sama juga dengan metode pembelajaran yang ada, Berikut ini beberapa metode pembelajaran yaitu: 1) Metode Ceramah. Menurut Muhibbin Syah, metode ceramah yaitu sebuah metode mengajar dengan menyampaikan informasi dan pengetahuan secara lisan kepada sejumlah peserta didik yang pada umumnya mengikuti secara pasif. Metode ceramah ini dapat digunakan pada implementasi kurikulum 2013. Namun, harus dikolaborasikan dengan metode yang lain, yang dapat memberikan kreativitas lebih kepada peserta didik. 3) Metode Tanya Jawab. Menururt Soetomo, metode Tanya jawab adalah suatu metode dimana guru menggunakan atau memberi pertanyaan kepada murid dan murid menjawab, atau sebaliknya murid bertanya pada guru dan guru menjawab pertanyaan murid itu. Metode ini dapat meningkatkan motivasi peserta didik dalam belajar, karena dengan sesering mungkin melakukan tanya jawab dengan guru peserta didik merasa mendapatkan perhatian lebih dari gurunya.4) Metode Diskusi. Muhibbin Syah, mendefinisikan bahwa metode diskusi adalah metode mengajar yang sangat erat hubungannya dengan memecahkan masalah (problem solving). Riskha pratama, dkk, 2010 :9) Metode ini menuntut peserta didik lebih aktif melakukan pembelajaran, setiap peserta didik diharapkan dapat memberikan sumbangan pemikiriran untuk dapat memecahkan sebuah masalah yang telah disajikan oleh guru. 5) Metode Demonstrasi. Metode demonstrasi adalah metode mengajar dengan cara memperagakan barang, kejadian, aturan, dan urutan melakukan suatu kegiatan, baik secara langsung maupun melalui penggunaan media pembelajaran yang relevan dengan pokok bahasan atau materi yang sedang disajikan. Metode ini sangat cocok untuk beberapa mata pelajaran seperti fisika, biologi, kimia, dan lain-lain 6) Metode Karyawisata. Metode karyawisata adalah metode pembelajaran yang mengajak peserta didik untuk mengunjungi objek-objek dalam rangka untum menambah dan memperluas wawasan objek yang dipelajari tersebut (sesuai dengan bidangnya). Metode ini disamping digunakan untuk pembelajaran, 
peserta didik juga dapat menggunakan kegiatan karyawisata sebagai ajang hiburan. Sehingga kegiatan pembelajaran tidak membosankan. 7) Metode Resitasi. Metode resitasi adalah metode penyajian bahan dimana guru memberikan tugas tertentu agar peserta didik melakukan kegiatan belajar. Setelah mengerjakan tugas yang diberikan diharapkan peserta didik lebih memahami materi yang telah diajarkan. 8) Metode Eksperimen. Metode eksperimen adalah metode atau cara dimana guru dan murid bersama-sama mengerjakan sesuatu latihan atau percobaan untuk mengetahui pengaruh atau akibat dari sesuatu aksi. ( Riskha pratama, dkk, $2010: 13$ )

Model penilaian yang digunakan pada kurikulum 2013 merupakan gabungan antara penilaian tradisional dan penilaian modern. Namun, penilaian modern lebih ditekankan untuk digunakan oleh para guru, karena dengan menggunakan penilaian modern berbagai karakter peserta didik dapat dinilai dengan melakukan pengamatan secara rutin. Selain itu bentuk penilaian peserta didik dalam buku rapor merupakan gabungan antara penilaian dengan angka, penialaian dengan abjad, dan penilaian dengan mendeskripsikan setiap kompetensi inti (KI) untuk setiap mata pelajaran. Sedangkan bentuk penilaian dengan angka memiliki rentang antara 1 s/d 4 dengan batas nilai minimum atau KKM sebesar 2,67. Setelah nilai angka didapat, nilai tersebut dikonversi kedalam bentuk abjad. Berikut ketentuan konversi nilai angka terhadap nilai abjad

\section{METODE PENELITIAN}

Rancangan penelitian yang dipergunakan dalam penelitian ini adalah rancangan penelitian deskriptif kuantitatif dengan pendekatan penelitian ex-post facto. Rancangan ini dipilih karena sesuai dengan permasalahan yang sebenarnya terjadi di lapangan. Sistem pengumpulan data dilakukan dengan menggabungkan pendekatan objektivisme dan subjektivisme. Pendekatan objektivisme merupakan pengumpulan data yang berpedoman pada hasil yang telah dicapai, artinya data yang diperlukan sudah ada dalam dokumen yang telah disusun secara sistematis dan ilmiah. Pendekatan subjektivisme merupakan pengumpulan data yang berasal dari tes dan wawancara yang telah direncanakan

\section{HASIL DAN PEMBAHASAN}

Populasi yang diambil dalam penelitian ini adalah peserta didik SMK Pelita. Sampel yang digunakan dengan tehnik Nonprobability sampling adalah teknik 
pengambilan sampel yang tidak memberikan peluang atau kesempatan sama bagi setiap unsur atau anggota populasi untuk dipilih menjadi sampel. Teknik sampel ini meliputi sampling sistematis, kuota, aksidental, puposive, jenuh, snowball.

Dalam penelitian ini sampel diambil dengan metode Taro Yamane, dengan pertimbangan bahwa bahwa metode ini lebih sering dipakai dalam penelitian kuantitatif Jumlah peserta didik SMK Pelita adalah 133 orang dengan jumlah sampel yang diambil adalah: 57

Dalam proses kegiatan penelitian terdapat beberapa cara untuk mengumpulkan data beberapa diantaranya adalah dengan mencermati data yang telah ada di tempat penelitian, observasi (pengamatan), angket (kuesioner), intevew (wawancara), dan lainlain.

Dalam penelitian ini untuk mengetahui bagaimana persepsi peserta didik terkait dengan implementasi kurikulum 2013 serta hubungannya dengan motivasi belajar siswa di kelas maka teknik pengumpulan data yang digunakan adalah angket.

Angket (kuesioner) merupakan teknik pengumpulan data yang dilakukan dengan cara memberi seperangkat pertanyaan atau pernyataan tertulis kepada responden untuk dijawabnya. Adapun angket dalam penelitian ini terdiri dari daftar pertanyaan yang diberikan kepada responden untuk proses pengumpulan data yang mengacu pada dua variabel. Variabel yang pertama adalah tentang persepsi peserta didik terkait dengan kurikulum 2013 sedangkan variabel yang kedua yaitu motivasi peserta didik dalam proses pembelajaran.

Angket yang diberikan berbentuk pertanyaan tertutup dengan alternatif jawaban berupa multiple choice seperti SS (sangat setuju), S (setuju), R (ragu-ragu), TS (tidak setuju), dan STS (sangat tidak setuju) atau pilihan SL (selalu), SR (sering), KD (kadangkadang), P (pernah), dan TP (tidak pernah)

Dalam penelitian digunakan skala Likert untuk mengukur dua variabel sekaligus terhadap responden yang sama, yaitu terkait dengan implementasi kurikulum 2013, dan bagaimana hubungannya dengan motivasi belajar peserta didik. Responden diminta untuk mengisi angket berupa pertanyaan tertutup dengan empat pilihan jawaban.

Kedua variabel yang diteliti menggunakan instrumen dengan jenis yang sama baik variabel X (implementasi kurikulum 2013) maupun variabel Y (motivasi belajar siswa di kelas) yaitu menggunakan angket dengan skala Likert. Berikut ini tabel kisikisi insturmen penelitian hubungan antara persepsi peserta didik tentang kurikulum 
2013 dengan motivasi belajar peserta didik di smk pelita ciampea.

Setelah proses pengambilan data (pengisian angket) selesai, maka tahapan penelitian dilanjutkan dengan menganalisis data dari mulai mendeskripsikan hasil pengisian angket sampai mengolah data tersebut untuk dapat menemukan korelasi antara variabel $\mathrm{X}$ dan variabel $\mathrm{Y}$. Sehingga, penulis dapat membuat kesimpulan dari hasil perhitungan-perhitungan tersebut. Adapun proses uji kelayakan dan perbaikan instrumen dilakukan beberapa hari sebelumnya.

Dari data skor perhitungan persepsi peserta didik tetang kurikulum 2013 di atas yang terdiri dari 57 peserta didik sebagai sampel diperoleh skor terendah sebesar 111 dengan skor tertinggi sebesar 175, range skor sebesar 64, skor rata-rata (mean) sebesar 148,13, median sebesar 149,03, dan modus sebesar 151,33, dengan menggunakan bantuan Ms. SPSS 9,

Dari data skor perhitungan motivasi belajar peserta didik di SMK Pelita Ciampea di atas yang terdiri dari 57 peserta didik sebagai sampel diperoleh skor terendah sebesar 90 dengan skor tertinggi sebesar 126, range skor sebesar 36, skor ratarata (mean) sebesar 105,8684, median sebesar 105,045, dan modus sebesar 99,5, berikut deskripsi data dengan menggunakan Ms. SPSS 9.

Untuk menguji kelayakan data yang didapat ari hasil angket, penulis melakukan uji normalitas data dengan menggunakan tekhnik Kolmogorov-Smirnov dengan ketentuan jika Sinifikan X dan Y lebih besar dari 0,05, maka data terdistribusi normal. Berikut ini uji Normalitas Kolmogorov-Smirnov dengan jumlah data 75.

Pada kolom terbawah, Asymp. Sig. (2-tailed), terlihat nilai variabel X (persepsi peserta didik tentang kurikulum 2013) sebesar 0,322, dan nilai variabel Y (motivasi belajar peserta didik) sebesar 0,617.

Semua nilai signifikan variabel lebih besar dari 0,05 sehingga disimpulkan bahwa data tersebut berdistribusi normal. Selanjutnya untuk mengetahui apakah terdapat hubungan antara variabel X (persepsi peserta didik tentang kurikulum 2013) dengan variabel Y (motivasi belajar peserta didik) di SMK Pelita Ciampea, maka dilakukan perhitungan korelasi produk momen, yaitu diperoleh 0,969

Dari hasil penelitian pada persepsi peserta didik tentang kurikulum 2013, didapatkan nilai tertinggi 175 nilai terendah 111 nilai rata-rata 148,26. Sehingga dapat dikatakan bahwa persepsi peserta didik tentang kurikulum 2013 memiliki fenomena yang cukup 
positif. Dari tabel tampak jelas nilai yang didapatkan peserta didik yang mendapatkan nilai tinggi mendominasi, atau dengan kata lain persepsi peserta didik tentang kurikulum 2013 sangat positif. Sedangkan untuk rekapitulasi nilai pada variabel Y (motivasi belajar peserta didik, nilai tertinggi yang didapatkan sebesar 126, nilai terendah sebesar 90, nilai rata-rata sebesar 105,93. Jika dilihat dari perolehan nilai ratarata yang didapatkan maka dapat dikatakan motifasi belajar peserta didik memiliki fenomena yang cukup positif.

Pada tabel di atas terlihat bahwa sebanyak 20 orang atau sebanyak 35,09\% respoden memiliki kriteria penilaian sangat tinggi, sehingga dapat disimpulkan bahwa motivasi belajar peserta didik sangat tinggi.

Selanjutnya peneliti melakukan uji normalitas data, hasil tes uji normalitas data dengan menggunakan sampel Kolmogoro-Smirnov pada variabel $\mathrm{X}$ bernilai 0,955 dengan probabilitas signifkasi 0,322 > 0,05 sedangkan pada variabel Y sampel Kolmogorov-Smirnov bernilai 0,756 dengan probabilitas signifikasi 0,617>0,05. Sehingga bisa disimpulkan bahwa baik variabel $\mathrm{X}$ maupun $\mathrm{Y}$ distribusi tes dinyatakan normal.

Setelah melalui uji normalitas penliti melakukan uji korelasi untuk mengetahui nilai korelasi antara variabel X dan varibel Y. sesuai dengan ketentuan Bab III. Dengan jumlah populasi sebanyak 133 orang, sampel yang diambil sebanyak 57 orang, dang dengan taraf signifikan sebesar 5\%. Penulis mendapatkan nilai korelasi antara variabel X danVariabel Y sebesar 0,969.

Selanjutnya untuk menentukan tingkat hubungan antara variabel $\mathrm{X}$ (persepsi peserta didik tentang kurikulum 2013) dengan variabel Y (motivasi belajar peserta didik) peneliti mengacu pada tabel 3.7. Kesimpulan yang dapat diambil adalah nilai korelasi product moment r-hitung sebesar 0,969 terletak pada interval 0,80-1,00. Yang artinya hubungan antara variabel $X$ (persepsi peserta didik tentang kurikulum 2013) dengan variabel Y (motivasi belajar peserta didik) di SMK Pelita Ciampea tahun 2015 sangat kuat.

\section{KESIMPULAN DAN SARAN}

\section{A. Kesimpulan}

Dari hasil penelitian hubungan persepsi peserta didik tentang kurikulum 2013 dengan motivasi belajar peserta didik di SMK Pelita Ciampea tahun 2015, dapat 
disimpulkan bahwa:

1. Persepsi peserta didik tetang kurikulum 2013 di SMK Pelita Ciampea memiliki fenomena yang positif, terbukti dari nilai maksimal yang dapat diperoleh peserta didik yaitu 185 , nilai tertinggi 175 , terendah 111 , rata-rata 147,74 .

2. Motivasi belajar peserta didik di SMK Ciampea memiliki fenomena yang positif, terbukti dari hasil angket dengan nilai maksimal yang dapat diperoleh sebesar 135, nilai tertinggi 126 , terendah 90 , sedangkan rata-ratanya 105,72.

Dari hasil uji korelasi produk momen hubungan antara persepsi peserta didik tentang kurikulum 2013 dengan motivasi belajar peserta didik memiliki nilai sebesar 0,969 sedangkan nilai r-tabel 0,266, dan 0,969 > 0,266 atau r-hitung > r-tabel. Dengan demikian dapat disimpulkan bahwa $\mathrm{HO}$ ditolak dan $\mathrm{H} 1$ diterima atau dengan kata lain terdapat hubungan yang positif antara variabel $\mathrm{X}$ (persepsi peserta didik tentang kurikulum 2013) dengan variabel Y (motivasi belajar peserta didik). Adapun tingkat hubungan antara variabel $\mathrm{X}$ dan variabel $\mathrm{Y}$ terletak pada interval 0,80-1,00 yang berarti tingat hubungan keduanya sangat kuat.

\section{B. Saran}

Dari hasil penelitian tentang hubungan antara persepsi peserta didik tentang kurikulum 2013 dengan motivasi belajar peserta didik di elas X Akuntansi SMK Pelita Ciampea tahun 2015, maka penulis memberikan beberapa saran sebagai berikut:

1. Disarankan kepada pihak manejemen sekolah untuk melanjutkan dan mengembangkan kurikulum 2013. Karena terbukti persepsi peserta didik tentang kurikulum 2013 memiliki hubungan yang positif dengan motivasi belajar peserta didik.

2. Penyelenggaraan kurikulum 2013 harus dikembangkan karena dari hasil angket, beberapa peserta didik masih memerlukan bimbingan untuk meningkatkan motivasi belajarnya.

3. Perlunya diadakan penelitian lebih lanjut terkait dengan pengaruh persepsi peserta didik tentang kurikulum 2013 terhadap motivasi belajar peserta didik, sehingga pihak penyelenggara pendidikan dapat mengevaluasi hal-hal apa saja yang perlu dirubah dan dikembangkan. Demi meningkatkan motivasi belajar peserta didik. 


\section{Referensi}

Arikunto, Suharsimi \& Cepi Safrudin Abdul Jabar. (2009). "Evaluasi program pendidikan". Jakarta: P.T Bumi Aksara

Arsyad, dan Sulfemi, Wahyu Bagja. (2014). Minat Siswa Tentang Keadministrasian dengan Hasil Belajar Administrasi Perkantoran. Edutecno. 9 (2), 40-50.

Badar, Dadan Samsul dan Sulfemi, Wahyu Bagja. (2014). Pengaruh Rasa Percaya Diri dan Motivasi Berprestasi Terhadap Kinerja di Kecamatan Ciampea Kabupaten Bogor. Edutecno. 10 (1), 1-10

Fajartriani, Tia dan Sulfemi, Wahyu Bagja. (2014).Pengaruh Motivasi Kerja Guru dan Iklim Organisasi Terhadap Kinerja Guru SMA Negeri di Kecamatan Cigudeg. Edutecno. 8 (1), 17-26

Karsiwan, Wawan dan Sulfemi, Wahyu Bagja. (2016). Hubungan Penerimaan Diri Dengan Kinerja Guru SD Di Kecamatan Pamijahan Kabupaten Bogor Edutecno. 15. (1). 1-10.

Dimyati dan Mudjiono. (2013). “Belajar \& Pembelajaran”. Jakarta: Rineka Cipta

Husmanah \& setyaningrum, yanuar. (2013). "Desain pembelajaran berbasis pencapaian kompetensi". Jakarta: Prestasi putaka publisher.

Mulyoto. 2013. “Strategi pembelajaran di era kurikkulum 2013”. Jakarta: Prestasi Pustaka Publisher

Nazir, mohammad. (2011). “Metode penelitian”.Bogor: Ghalia indonesia

Rahmat, Arif. (2013). "Hubungan persepsi siswa tentang kompetensi pedagogik guru dengan hasil belajar siswa”. Skripsi. Bogor. STKIP Muhammadiyah

Republik Indonesia. Undang-undang dasar 1945.

Sogiyono. (2009). “Metode penelitian pendidikan'. Bandung: Alfabeta, CV.

Sulfemi, Wahyu Bagja. (2013). Pengaruh Persepsi Siswa atas Kemampuan Pedagogik Guru dan Motivasi Belajar Siswa Terhadap Prestasi Belajar Ilmu Pengetahuan Sosial Siswa (Survei di SMK Swasta Kabupaten Bogor). Edutecno. 7 (2), 17 26.

Sulfemi, Wahyu Bagja. (2015). Pengaruh Metode Pembelajaran Kontekstual dan Penggunaan Media Video Pendidikan Terhadap Hasil Belajar IPS. Edutecno. $13(2), 1-10$.

Sulfemi, Wahyu Bagja. (2015). Challenges Of Indonesian Teacher Competence in dealing with Asean Economic Cummunity (AEC). Engglis Forum. 1 (1), 6979

Sulfemi, Wahyu Bagja. (2015). Kemampuan Pedagogik Guru. Prosiding Seminar Nasional. STKIP Muhammadiyah Bogor 1. (1). 71-83. 
Sulfemi, Wahyu Bagja. (2016). Hubungan Persepsi Peserta Didik Tentang Kompetensi Guru Mata Pelajaran Sejarah dengan Hasil Belajar Mata Pelajaran Sejarah di Kelas X SMA Negeri 1 Pamijahan Kabupaten Bogor. Fascho, 5 (2), 52-70.

Sulfemi, Wahyu Bagja. (2016). Hubungan antara Persepsi Guru pada Kepemimpian Kepala Sekolah dan Motivasi Guru dengan Kinerja guru dalam Proses Pembelajaran di SMA Negeri 1 Ciomas. Fascho : Kajian Pendidikan dan Sosial Kemasyarakatan, 5 (1), 36-55.

Sulfemi, Wahyu Bagja. (2016). Kompetensi Profesionalisme Guru Indonesia dalam Menghadapi MEA. Prosiding Seminar Nasional STKIP Muhammadiyah Bogor. 1 (1), 62-77.

Sulfemi, Wahyu Bagja. (2017). Analisis Pengaruh Motivasi Dan Disiplin Terhadap Kinerja Guru (Studi Kasus di SMA Negeri 1 Pamijahan Kabupaten Kabupaten Bogor). Prosiding Seminar Nasonal STKIP Muhammadiyah Bogor. 1 (1), 342357.

Sulfemi, Wahyu Bagja dan Lestari, Ayu Hopilatul. (2017). Korelasi Kompetensi Pedagogik Guru dengan Prestasi Belajar Mata Pelajaran IPS Di SMP Muhammadiyah Pamijahan Kabupaten Bogor. Edutecno. 16 (1), 1-16

Ormrod, Jeanne Ellis, (2002). “psikologi pendidikan” Jakarta: Erlangga

Trianto. (2007). Model Pembelajaran Terpadu dalam Teori dan Praktek. Jakarta: Prestasi Pustaka 